\title{
Ambivalence Toward Men: Comparing Sexism Among Polish, South African and British University Students
}

\author{
Magdalena Zawisza \& Russell Luyt \& \\ Anna Maria Zawadzka
}

\begin{abstract}
This study extends the literature on attitudes toward gender roles by exploring whether the nature of sexism (i.e., benevolence and hostility directed at men) differs among university students from two under-researched countries, Poland (n 0190) and South Africa (n 0188), in a comparison with students in the United Kingdom (n0166). Based on empirical literature applying Ambivalent Sexism Theory, and in the light of the socio-political context, it was hypothesized that: (1) both hostile and benevolent attitudes toward men in Poland would be more liberal than in South Africa and more conservative than in the United Kingdom, and (2), women would exhibit more hostile but less benevolent attitudes than men in relatively more conservative South Africa. The Ambivalence to Men Inventory was used to measure the two types of sexist attitudes about men. Findings supported the first hypothesis for hostile attitudes and partially for benevolent attitudes. South African and Polish students were more benevolent and hostile to men than British students, and students from South Africa were more hostile than those from Poland. Moreover, as predicted, a significant country-bygender interaction revealed that South African women had more hostile and less benevolent attitudes to men than South African men. No such gender gap was present in the case of hostile attitudes in Poland and benevolent attitudes in the United Kingdom. Findings are discussed in terms of Ambivalent Sexism Theory and the countries' socio-cultural context.
\end{abstract}

against stable democracy of the United Kingdom. We argue that the different nature of the transition contributes toward the distinct patterns of sexism observed in these countries today. Specifically, we discuss the varied emphasis on gender equality policies in the countries' history of transition: history of legalized inequality in South Africa (Hassim 2005) vs. forced emancipation of communism in Poland (LaFont 2001). Thus, and of interest to cross-cultural researchers, this paper illustrates the importance of taking socio-political context into consideration when attempting to understand sexism. Moreover, we focus on attitudes to men rather than women, which are somewhat neglected in the literature (Glick 2004). This paper also recognizes the multi-dimensional and ambivalent, rather than onedimensional and exclusively negative, nature of sexism (Glick et al. 2004). In doing so, we expand upon existing knowledge concerning sexism cross-culturally.

Sexism-sexist or traditional gender attitudes-is defined as a dominant traditional set of ideologies whose function is to maintain gender inequality (Glick and Fiske 2001a; Glick et al. 2004; Viki and Abrams 2004). On the other hand, egalitarianism-egalitarian or liberal gender

Keywords Ambivalent sexism · Gender attitudes · Poland · United Kingdom · South Africa

\section{Introduction}

This paper sets out to address a number of gaps in the crosscultural literature on sexism. Uniquely, it compares attitudes to men in three countries-Poland, South Africa and the United Kingdom-and analyses them in light of sociopolitical context. Poland and South Africa represent two under-researched countries undergoing transition to democracy (Lewicka 2005; Hassim 2002) and are compared 
attitudes — can be understood as an antonym of sexism: ideologies that promote gender equality (McDaniel 2008). Over the past two decades, ample research has investigated such gender attitudes cross-culturally through the use of mostly student samples recruited across five continents (i.e., 16 nations, Glick et al. 2004; 14 nations, Williams and Best 1982; Williams et al. 1999). However, whilst many studies have examined attitudes toward women (Glick and Fiske 1996, student and nonstudent U.S. samples; Glick et al. 2000, a mixture of representative and student samples from 19 countries; Swim et al. 1995, U.S. student samples; Tougas et al. 1995, male student and male worker samples from Canada; Twenge 2001, U.S. student samples), only a few have focused on attitudes toward men (Glick and Fiske 1999, U.S. student and older adults samples; Glick et al. 2004). In addition, the majority of those studies treated these attitudes as a global construct and did not distinguish between hostile and benevolent sexism, thus limiting our understanding of the exact nature of sexism (with the exception of two cross-culural investigations on mainly student samples by Glick et al. 2004; and Glick et al. 2000; and Yakushko 2005 on Ukrainian college students and young professionals).

According to Ambivalent Sexism Theory (AST, Glick 2004; Glick et al. 2000), traditional—or sexist—gender attitudes are not one-dimensional in nature but ambivalent. Cross-culturally, they consist of both hostile and benevolent components, whose coexistence results in general ambivalence. The function of both types of attitudes serves hierarchy stabilization (Glick and Fiske 2001a; Glick et al. 2004; Viki and Abrams 2004) in private and public spheres alike (Glick and Fiske 2001b). Hostile attitudes indicate antipathy toward men (Hostility to Men, HM) or women (Hostile Sexism, HS), whilst benevolent attitudes are characterized by positive but still patronising beliefs about certain groups of men (Benevolence to Men, BM) or women (Benevolent Sexism, BS) (Becker 2010; Sibley et al. 2007; Sibley and Wilson 2004). As the understanding and manifestation of sexism have been changing from more overt to more subtle forms (Glick and Fiske 1996, 1999; Swim et al. 2005, U.S. student sample), investigating both overt hostile and more subtle benevolent aspects of sexism is crucial in cross-cultural comparisons.

Since the United Kingdom has consistently scored amongst the most egalitarian countries across five continents on both one-dimensional measures of sexism (Williams and Best 1990, mostly student samples from 14 countries) as well as on benevolent and hostile attitudes to men (Glick et al. 2004, mainly student samples from 16 nations) and women (Glick et al. 2000, mixture of representative and student samples from 19 countries), it has been included in the present investigation as a reference point for the more under-researched countries: Poland and South Africa. Neither of the latter countries was included in Glick et al.'s (2004) investigation on ambivalent attitudes toward men.
Crucially, in the case of this paper, while AST predicts different shape of gender gap depending on the type of sexism and the national level of gender inequality (men underscoring women on HM but outscoring them on BM, particularly in countries with high gender inequality, Glick et al. 2004) the theory is limited in predicting the national level of sexism in the first place. This paper is among the first to offer analysis of countries' socio-political context as a way to address this issue. Specifically, different emphasis on gender equality in Poland and South Africa during their transition to democracy over the past 20 years (i.e. history of legalized inequality in South Africa vs. forced emancipation of communism in Poland; Hassim 2005; LaFont 2001) is argued to be useful in accounting for differing degrees of sexism nationally (higher in South Africa than in Poland). Moreover, socio-political context is also useful in explaining some unexpected findings, from AST's point of view, concerning the shape of the gender gap (or lack of it) on particular types of sexism. Such an analysis goes beyond AST and may enrich our understanding of how different types of sexism function to maintain the status quo in different countries. Thus, analysis of sexism in countries undergoing transition may be especially informative of how socio-political context relates to gender attitudes. Two key questions are examined: (1) What is the nature of attitudes toward men in Poland and South Africa as compared to those in the United Kingdom?; and (2), How do men compare to women regarding their attitudes toward men in each of the three countries? Additionally, our data concerning attitudes toward men in the United Kingdom will enable indirect confirmation of previous findings concerning the country's relative gender egalitarianism.

\section{Nature of Sexism in Poland, South Africa and the United Kingdom}

The first question investigated in the current paper is how the two under-researched countries, Poland and South Africa, compare to the relatively egalitarian United Kingdom in their sexist attitudes toward men. Since research applying AST has shown that ambivalent sexism correlates positively and significantly with social indicators of equality, such as the Gender Empowerment Measure (GEM, e.g., women's presence in elite occupations and roles) and the Gender-Related Development Index (GDI, e.g., women's overall standard of living), one could argue that sexist attitudes in the three countries might be predicted based upon such socio-economic indices. However, the latest Human Development Report ("United Nations Development Programme” 2009) returns contradictory results. Whilst the latest GEM analysis ranks the United Kingdom as most egalitarian (15th worldwide; 0.79), followed by South Africa (26th worldwide; 0.687) and then Poland (38th 
worldwide; 0.631), the most recent GDI analysis ranks the United Kingdom as most egalitarian (17th worldwide; 0.943), followed by Poland (39th worldwide; 0.877) and then South Africa (109th worldwide; 0.680). The observed variation might partly be due to the different, yet related, aspects of equality these indices capture (i.e., women's occupational and managerial roles for GEM vs. women's general standard of living for GDI). However, it may also indicate, as Bhana et al. (2008, p. 118) argue, "that great variability exists in how gender role attitudes are enacted. This is likely to be even more complex in a society in transition..." such as Poland and South Africa. Indeed, out of the three countries, the United Kingdom is the only one which scores consistently as highly egalitarian on both socio-economic indices such as GDI and GEM and on psychological measures such as gender attitudes or ambivalent sexism as shown above.

Interestingly, the United Kingdom is also the most mature democracy of the three countries (spanning 300 years, compared to some 20 years in Poland and South Africa). It also is considered to be amongst the most developed countries in the world, with a long history of modernization-a factor argued to contribute significantly to gender equality worldwide (Inglehart and Norris 2003). Indeed, the feminism movement in the United Kingdom dates back to 1800 , even though full women's suffrage was not achieved until 1928; this compared to 1918 in Poland and 1994 in South Africa when the initial suffrage granted to White women in 1930 was extended to include Black women. But full gender equality has arguably still not been achieved in the United Kingdom. Some sources report a marked slowdown in egalitarian trends since the early '80s (Blau et al. 2006; Dorius and Alwin 2010; Scott 2006) and even debate the possibility of trend reversal or a return to sexism (Braun and Scott 2009; Crompton et al. 2005; Walter 2010). Pessimists argue that further development of gender equality is unlikely due to the asymmetry in adopting new gender roles, with women's increased participation in maledominated jobs not matched by an increase in men's participation in sharing household responsibilities (England 2006). Thus, there is a need to continuously monitor the level of sexism in the relatively egalitarian United Kingdom.

Poland and South Africa, being in transition, represent intriguing cases for those interested in cross-cultural attitudes toward male gender roles. Gender attitudes in these countries are arguably in a state of flux because of dramatic contemporary economic, political, and social changes (Lewicka 2005). There are important similarities as well as differences between these two countries. Both countries are amongst the biggest and fastest-developing in their respective regions. Dynamic socio-economic changes, a long history fighting for independence, and a relatively youthful fully democratic system established in the early '90s may be listed amongst the similarities between these otherwise culturally very different countries. Notably, the transition has taken somewhat different routes in each of these countries, which might have affected gender attitudes in different ways.

Over the past two decades, South Africa has undergone a transition from apartheid to majority political rule which culminated in democratic elections in 1994. In South Africa's case, and in contrast to other African countries, the transition to democracy led to placing (gender) equality concerns into the centre of democratic debates (Hassim 2002). Feminist participation in processes of transition has resulted in greater legal and political equality for women (Hassim 2005). This is evidenced constitutionally as well as legislatively in women's relatively strong representation within government (Waylen 2004). It is also indexed by the GEM. However, cultural and social gender equality is less easily evidenced.

Although South Africa's transition to democracy has been perceived as a success story in gender terms, this progress is relative. Apartheid's legacy of deeply rooted and institutionalized inequality marks the starting point for changes toward the full democracy which followed. Indeed, power remains unevenly distributed in this highly stratified society. With regard to gender equality, Shefer et al. (2008) interviewed a sample of men and women in the Western Cape and report that although a clear shift in gender relations has taken place, with women gaining power, this process has not been absolute and complete. Women and men in the Western Cape province continue to construct their gender identities and roles in terms of traditional gender relations of dominance and subservience. Mantell et al. (2009) similarly report tensions between changing gender norms in post-apartheid South Africa which recognise women's rights (or lack thereof) and traditional gender norms acting to limit such freedoms. Dodoo and Frost (2008, pp. 432-433), based on an overview of the literature on subSaharan Africa, make an even stronger statement that "pervasive gender inequality is intimately intertwined in the fabric of sub-Saharan African society.” Gender conservatism has also been evidenced recently in a study of gender representation in television advertising in this country (Luyt 2011).

How, then, would South African attitudes toward men compare to those in the United Kingdom? Although research on ambivalent attitudes toward men did not include South Africa (Glick et al. 2004), in earlier cross-cultural investigations on ambivalence toward women (Glick et al. 2000), as well as on one-dimensional attitudes to women (Williams and Best 1990), South Africa scored amongst the most conservative countries out of the 16 and 14 nations respectively. Crucially, Glick et al. (2004) showed that ambivalent attitudes toward women (i.e., HS and BS) correlate highly, significantly, and positively with attitudes toward men (i.e., HM and BM) in most of the 16 countries for male 
participants (exceptions being Portugal and Syria) and in all 16 countries for female participants. This finding confirmed the AST's prediction that HM and BM, as well as HS and BS, are complementary gender ideologies which function to maintain the status quo. Thus, although South Africa was not included amongst these 16 countries, the reviewed literature consistently reports that it is more gender conservative than the United Kingdom. Even though the data refers largely to attitudes to women, AST states that both forms of ambivalent attitudes (i.e., those directed at men and women) are compatible ideologies which aim to maintain the status quo (Glick and Fiske 2001a). This has been supported by robust cross-cultural correlations between HS and $\mathrm{HM}$ as well as BS and BM (Glick et al. 2004). Thus, based on AST, and the long history of inequality endured in South Africa, as compared to long history of democracy in the United Kingdom, it could be predicted that participants in South Africa should score higher than the British sample on both HM and BM.

Predicting how Poland would compare to the United Kingdom and South Africa on attitudes toward men is difficult because of a lack of data on Poland in both of Glick et al.'s $(2000,2004)$ cross-cultural studies on ambivalent sexism. Its historical and socio-political background makes Poland a mixed constellation of factors which may influence gender attitudes in conflicting ways. Its transition to democracy had a different starting point, and thus nature, from South Africa's. Historically, democracy in Poland was preceded by communism rather than by a period of legalized inequality. Communist values were informed by idealistic Marxist and Leninist theories of women's equality (Yakushko 2005) and were thus egalitarian in nature. Indeed, they were manifested in '80s statistics unheard of in the democratic West: close to $90 \%$ participation of workingage women in the employment market and $30 \%$ of seats in governing bodies guaranteed to women via a system of quotas (LaFont 2001; Pollert 2003; Seguino 2007). However, this (seeming) emancipation in the public sphere was not accompanied by equality in the domestic sphere (Shafiro et al. 2003). Women experienced the so-called 'triple burden': they were expected to perform the roles of worker, mother and social activist (LaFont 2001). Hence, the transition into (male) democracy in 1989 was marked by rejection of communist ideas (including the politically imposed women's emancipation), reinforcement of motherhood, loss of the few benefits women had, and remasculinisation of the system (LaFont 2001; Pollert 2003; Seguino 2007; Yakushko 2005).

Thus, conflicting forces are at work in Poland. On the one hand, more liberal gender roles are facilitated by the process of progressive modernization (Inglehart and Norris 2003) and the individualistic values promoted by (patriarchal) capitalism (Gibbons et al. 1991). On the other hand, traditional division of labour and power between Polish men and women is reinforced by the rejection of egalitarian communist ideas and encouraged by the dominant Catholic Church promoting strong traditional family values (Robila and Krishnakumar 2004). This mixture of factors might have, at least in part, contributed to the contradictory findings returned by GEM and GDI mentioned earlier ("United Nations Development Programme” 2009). Thus, it is important to turn from socio-economic indices of gender egalitarianism (e.g., GEM or GDI) to psychological ones such as direct measures of gender attitudes.

Central and Eastern European countries have been included in few psychological cross-cultural studies which used such direct measures (e.g., Frieze et al. 2003, Slovenian, Croatian and U.S. student samples; Levant et al. 2003, Russian and U.S. young men and women; Shafiro et al. 2003, Ukrainian and U.S. female students) and have demonstrated their greater gender conservatism as compared to Western nations. On the whole, studies of this sort have overlooked Poland. We are aware of only few international studies which include Poland (i.e., Forbes et al. 2004; Olson et al. 2007; Robila and Krishnakumar 2004). These studies suggest that Poland, when compared to other Eastern European countries, ranks as moderately conservative. Specifically, in terms of gender attitudes tested using samples of men and women aged 18-40, Poland scored more conservative than East Germany but less conservative then Bulgaria and Hungary, as did Slovenia, Russia and the Czech Republic (Robila and Krishnakumar 2004). In terms of gender role equality tested using student samples, Poland scored as more liberal than Albania, Lithuania, Russia and Croatia but as less liberal than the Czech Republic, Hungary, Slovenia, the USA and Slovakia (Olson et al. 2007). Compared to students of Western nationalities, such as Italians or Germans, Polish students list male and female roles which are more genderpolarized in terms of the traditional division of labour (Boski et al. 2007). At the same time, Polish students were positioned as more conservative than those in the United States (Forbes et al. 2004; Olson et al. 2007).

To our knowledge, Forbes et al. (2004) is the only example of cross-cultural study into ambivalent sexism specifically which also includes Poland. However, this study focused on ambivalent attitudes toward women and tested only female students. Nevertheless, to the extent that hostile and benevolent attitudes to women and men are a compatible set of traditional gender ideologies (as posited by AST and shown in Glick et al. 2004), Forbes et al.'s (2004) study suggests that Poland will score as more benevolent and hostile to men than a Western country such as the United Kingdom.

As discussed above, previous cross-cultural research on ambivalent sexism, combined with AST's assertion that attitudes to men and women are compatible ideologies, informs predictions concerning Poland and South Africa in 
comparison to the United Kingdom. It is limited, however, in explaining how Poland compares to South Africa. Our analysis of Poland and South Africa's unique but different nature of transition to democracy is useful here. The history of legalized inequality in South Africa as a result of apartheid, compared to a period of forced emancipation in Poland under communism, suggest higher levels of gender inequality (and thus sexism) in the former country prior to their 20 years of democratization. Thus, although no study has made direct comparison of ambivalent attitudes toward men in Poland, South Africa, and the United Kingdom, based on the empirical and theoretical literature outlined above, as well as the analysis of their unique socio-political contexts, it could be predicted that these countries may lie along a continuum where South Africa is more sexist than Poland, whilst the United Kingdom is more egalitarian than both. Since HM and BM are compatible ideologies this main effect of country should emerge for both types of sexist attitudes: HM (H1a) and BM (H1b). However, men and women in each country may score differently on specific types of attitudes.

\section{Gender Gap in Attitudes toward Men in Poland, South Africa and the United Kingdom}

The second central research question concerns how men compare to women on ambivalent attitudes toward men within each of the three countries. There is ample crosscultural evidence that women are more liberal in their gender attitudes than men. For example, Williams and Best (1990) reported that female students had more progressive gender ideologies than male ones in 14 countries drawn from across North and South America, Africa, Europe, and Asia (Malaysia and Pakistan proved the exception). The few studies which have included Central and Eastern European countries also suggest greater egalitarianism amongst women as compared to men. This was shown for overall gender equality tested among students from Albania, Croatia, the Czech Republic, Hungary, Lithuania, Russia, Slovakia, Slovenia and Poland (Olson et al. 2007) and for attitudes toward women among students from Croatia, Slovenia and the USA, (Frieze et al. 2003) as well as among young men and women from the Russia and USA (Levant et al. 2003).

When it comes to ambivalent attitudes to men, the picture is more complex and depends on the type of attitudes. Recent research involving 16 nations has established that in the majority of countries, excluding the United Kingdom, female students express HM to a greater extent than male students (Glick et al. 2004). Findings regarding BM were, however, more varied. Whilst men rated higher on BM than women in 11 countries, men and women did not differ on $\mathrm{BM}$ in the remaining five countries (i.e., Argentina, the United Kingdom, Singapore, Syria, and Colombia). This pattern was largely mirrored in the Ukraine, where female students, compared to male students, held more hostile attitudes toward men but did not differ significantly from men on BM (Yakushko 2005).

AST, which borrows from group and social justice theories, provides an explanation for these differential scores on $\mathrm{HM}$ and BM in men and women. For women, their typically higher endorsement of HM than men is indicative of their rejection of male power so as to protect their in-group. Most men, on the other hand, are motivated to reject HM (more so than women) in recognition that it evaluates their gender group negatively. Thus, endorsing hostile attitudes toward men protects female in-group interests, whilst rejecting such hostility protects male in-group interests. This leads to a gender gap on hostile sexism where women outscore men. This main gender effect on HM is indeed seen in most countries (Glick et al. 2004). Since BM emphasizes men's virtues (their fit-for-higher-status roles and ill-fit for domestic responsibilities), the consistently higher scores of men compared to women on this scale in a majority of countries are not surprising and similarly reflect in-group favouritism. Thus the theory and empirical evidence suggest that women should score higher than men on HM but lower than men on BM. In other words women, compared to men, should be more hostile but less benevolent to men.

However, this may not hold true for all countries. Specifically, the literature further suggests that the main effects of gender and country may be qualified by significant interactions between country and gender. According to AST, the more gender-traditional the country the greater women's motivation to resent male power (as it maintains the unequal status quo). Larger gender gap between men and women, with women scoring higher on HM, is therefore likely. Furthermore, in response to female hostility, men in such conservative countries may be particularly motivated (more so than women) to endorse the in-group favoring BM. Thus, we predict that the gender gap on HM, where women outscore men, should hold for relatively gender-conservative South Africa (H2a) but would not be expected for the relatively liberal United Kingdom. This was apparent in Glick et al. (2004) where British male students scored equally as low as British female students on HM. This prediction would be confirmed by a significant gender $\mathrm{x}$ country interaction, and when followed up, would return significant simple effect of gender for South Africa.

According to AST, the in-group favouritism, manifested by men scoring higher on BM than women, should hold for more conservative South Africa (H2b) but would not be expected for the egalitarian United Kingdom. This prediction, similarly, would be supported by a significant gender $\mathrm{x}$ country interaction where the simple effect of gender would reach significance in South Africa. Indeed, empirical evidence shows that the gender gap on BM in the United 
Kingdom is non-significant (Glick et al. 2004). Although the authors do not provide explanation for this phenomenon, it is possible that the more gender-liberal a country, the less tension - or greater agreement - there is between men and women regarding BM. Since the reviewed literature suggests that Poland might be moderately conservative, it is difficult to predict the nature of the gender gap on HM or $\mathrm{BM}$ in this country based on AST. It will therefore be explored rather than predicted here.

In summary, we predict that:

H1a (main effect of country for hostility to men): Students in South Africa will be significantly more hostile to men than those in Poland, whilst the British students will be significantly less hostile to men than both other samples.

H1b (main effect of country for benevolence to men): Students in South Africa will be significantly more benevolent to men than those in Poland, whilst the British students will be significantly less benevolent to men than both other samples.

H2a (gender x country interaction for hostility to men): Female students will be significantly more hostile to men then male students in South Africa.
$\mathrm{H} 2 \mathrm{~b}$ (gender $\mathrm{x}$ country interaction for benevolence to men): Female students will be significantly less benevolent to men then male students in South Africa

\section{Method}

\section{Participants}

Student participants were recruited through means such as campus leaflets and e-mails. They were offered remuneration for their time. Our initial samples consisted of 175 British undergraduate students (48\% females and 52\% of males), 193 Polish students (53\% females and $47 \%$ of males) and 190 South African students (38\% females and $62 \%$ of males). Since the age range in the United Kingdom was considerably higher than in Poland and South Africa (sds 05.09, 2.66 and 2.22 respectively) and age is known to be linked to sexism (Dorius and Alwin 2010; Scott 2006; Swim et al. 2005) 14 participants aged 30 or more were removed from further analyses. Even though all analyses with and without these participants return the same results it was thought that removing them will aid comparisons with

Table 1 Comparison of demographic profile of the samples by country and gender

\begin{tabular}{|c|c|c|c|c|c|c|}
\hline & \multicolumn{2}{|c|}{ United Kingdom } & \multicolumn{2}{|l|}{ Poland } & \multicolumn{2}{|c|}{ South Africa } \\
\hline & $\mathrm{F}$ & M & $\mathrm{F}$ & M & $\mathrm{F}$ & M \\
\hline \multirow[t]{2}{*}{ Number of participants } & $78(48)$ & $86(52)$ & $102(54)$ & $88(46)$ & $70(38)$ & $118(62)$ \\
\hline & 166 & & 190 & & 188 & \\
\hline \multirow[t]{2}{*}{ Age (mean years) } & 19.10 & 19.86 & 21.75 & 21.70 & 20.20 & 20.71 \\
\hline & $19.50^{\mathrm{a}}$ & & $21.73^{\mathrm{b}}$ & & $20.52^{c}$ & \\
\hline \multicolumn{7}{|l|}{ Ethnic origin } \\
\hline White & $63(38.2)$ & 77 (46.7) & $102(53.7)$ & $88(46.3)$ & $5(2.7)$ & $46(24.5)$ \\
\hline Black & $2(1.2)$ & $1(.6)$ & 0 & 0 & $6(3.2)$ & $10(5.3)$ \\
\hline Asian & $8(4.8)$ & $6(3.6)$ & 0 & 0 & $10(5.3)$ & $13(6.9)$ \\
\hline mixed & $4(2.4)$ & $3(1.8)$ & 0 & 0 & 39 (20.7) & $36(19.1)$ \\
\hline unknown & $1(.6)$ & 0 & 0 & 0 & $11(5.9)$ & $11(5.9)$ \\
\hline other & 0 & 0 & 0 & 0 & 0 & $1(.5)$ \\
\hline \multicolumn{7}{|l|}{ Course of study } \\
\hline Social sciences \& arts & 64 (39) & $66(40.2)$ & $93(49.2)$ & $65(34.4)$ & $51(26.8)$ & $47(24.7)$ \\
\hline science & $2(1.2)$ & $4(2.4)$ & $1(.5)$ & 19 (10.1) & 20 (10.5) & $61(32.1)$ \\
\hline joined & $8(4.9)$ & 17 (10.4) & 7 (3.7) & $1(.5)$ & 0 & $4(2.1)$ \\
\hline unknown & $3(1.8)$ & 0 & 0 & $3(1.6)$ & 0 & 7 (3.7) \\
\hline
\end{tabular}

Percentages are in parentheses. Means within a row with different superscripts are significantly different at $\mathrm{p}<05$. Three-way hierarchical loglinear analyses were conducted on counts to test for main and interaction effects of gender and country on: (1) ethnic origin, and (2) course of study separately. The likelihood ratio for both models was $\chi^{2}(0) 00$, p01 indicating perfect goodness of fit in both cases. For the former only second order interactions were significant: country $\mathrm{x}$ gender, $\chi^{2}$ (2)033.22, $\mathrm{p}<.001$; country x ethnicity, $\chi^{2}$ (10)0342.79, $\mathrm{p}<.001$; and gender $\mathrm{x}$ ethnicity, $\chi^{2}$ (5) 026.87, $\mathrm{p}<.001$. For the latter 3-way interactions reached significance: $\chi^{2}(6) 028.78, p<.001$. Thus, in both cases the gender $\mathrm{x}$ country groups differed significantly on specific levels of ethnicity and course of study in complex ways. E.g., as illustrated by the counts per cell above, there were more White men then White women in the South Africa sample; and more men than women studied sciences in Poland and South Africa 
other student samples in the future. This reduced the samples by nine participants in the United Kingdom (four women and five men), three (males) in Poland and two (of each gender) in South Africa resulting in total of 544 participants (see Table 1 for the demographic profile of this reduced sample).

\section{Sample 1: United Kingdom}

Data from 166 British undergraduate students (48\% females and $52 \%$ of males) from Royal Holloway, University of London and the University of Winchester were included in the analyses. They averaged 19.5 years of age, ranging from 18 to 29 (sd 01.96). Nearly 85\% of them identified as White, followed by $8.4 \%$ Asian, $4.2 \%$ mixed, $1.8 \%$ Black and .6\% of unknown ethnic origin. Most studied social sciences (including psychology) and arts (79.2\%), followed by joint programmes (15.3\%), science (3.6\%), and unknown subjects $(1.8 \%)$.

\section{Sample 2: Poland}

Data from 190 Polish students (54\% females and 46\% of males) from Gdansk University were included in the analyses. They averaged 21.73 years of age, ranging from 19 to 28 (sd 01.78). All where White; the majority were recruited from the psychology and arts departments (83.6\%), whilst the remaining studied science (10.6\%), joint programmes (4.2\%), and unknown subjects (1.6\%).

\section{Sample 3: South Africa}

Data from 188 South African students (38\% females and $62 \%$ of males) from the University of Cape Town were included in the analyses. They averaged 20.52 years of age, ranging from 18 to 26 (sd 01.70 ). Nearly $40 \%$ identified as 'coloured or mixed,' $27.2 \%$ as White, $12.2 \%$ as Asian, $11.8 \%$ as unknown or other, and $8.6 \%$ as Black. Students were recruited from psychology, other social sciences and arts (51.5\%), sciences (42.6\%), joint programmes (2.1\%), and unknown subjects (3.7\%).

\section{Comparability of Sample Characteristics}

The samples were comparable in terms of education (they were all university students). They differed in age, with the Polish sample being oldest (M021.73) followed by South African (M020.52) and British (M019.50) samples, F $(2,544) 052.90, \mathrm{p}<.001$. This reflects differences in educational systems: Polish students start their higher education at the age of 19 (instead of 18) and study for their first university degree for five (instead of three) years. In the UK on the other hand there are more mature students (i.e. older than 21) than in South Africa.

The samples were comparable in terms of gender distribution, which was close to equal except for South Africa, where males were slightly overrepresented (62\%). Analyses on randomly selected gender-balanced samples returned the same findings as the analyses reported below, thus confirming the comparability of these samples in terms of participants' gender. Each sample included only nationals of the tested country.

As expected, the samples differed in terms of ethnic origin. Typically for their nationality, the Polish sample was $100 \%$ White, compared to $84.9 \%$ in the United Kingdom and $27.2 \%$ in South Africa. There was a higher percentage of 'Coloured or Mixed' (39.8\%) and Asian (12.2\%) participants in South African than in the British sample (4.2\% and $8.4 \%$ respectively). In the United Kingdom $1.8 \%$ (compared to $8.5 \%$ in South Africa) identified as Black, but $11.8 \%$ in the South African sample did not identify their ethnic origin. Luyt (2005) suggests that participants in South Africa may be particularly sensitive to such classification due to the country's history of legalized race discrimination and therefore more unwilling to classify themselves as belonging to specific population groups.

Whilst the majority of participants in Poland (83.6\%) and the United Kingdom (79.2\%) studied psychology and other art subjects, in South Africa only $51.5 \%$ of participants were recruited from these departments. The samples also differed in the number of science students $(42.6 \%$ in South Africa, $10.6 \%$ in Poland, and 3.6\% in the United Kingdom) and joint programme students (15.3\% in the United Kingdom, 4.2\% in Poland, and 2.1\% in South Africa).

The distribution of participants across the various demographic categories was additionally analysed as a function of gender and country using hierarchical threeway loglinear analyses. These returned significant second and third order effects showing predictable differences in demographic profiles and reflecting typical demographics of student samples in the three countries (see Table 1).

\section{Design and Procedure}

A 3 (country: the United Kingdom, Poland, South Africa) $\mathrm{x}$ 2 (participants' gender: male vs. female) between-subjects design was adopted where dependent variables included hostile and benevolent attitudes toward men.

Individuals participated in small groups, and each participant was provided with a booklet containing an information sheet with a cover story (i.e., the supposed purpose of the study was to validate one of the tools measuring gender attitudes), a consent form, the Ambivalence toward Men Inventory (AMI, Glick and Fiske 1999), and a debriefing 
note which explained the real purpose of the study. The session took approximately $30 \mathrm{~min}$.

\section{Measures}

Glick and Fiske's (1999) AMI was used to measure sexist attitudes toward men. This is arguably one of the more sensitive explicit measures of attitudes toward men which is currently available (Glick and Fiske 1999; Glick et al. 2004). This tool contains a six-point Likert-type response format (0-disagree strongly; 5-agree strongly), where 20 items measure hostile and benevolent attitudes to men. Evidence for AMI's discriminant and convergent validity has been provided by Glick and Fiske (1999), and evidence for its cross-cultural validity has been provided by Glick et al. (2004). The scale was administered in English in South
Africa and the United Kingdom and translated into Polish for use in Poland. The Polish translation was back-translated into English, and any ambiguities in the translation were resolved via discussion (see the Appendix for the translations and Table 2 for the original item wording).

In order to test invariance, a replicatory factor analysis was conducted following Ben-Porath's (1990) recommendation: The same factor analytic procedure with Varimax solution and forced two-factor extraction was conducted for each sample. A two-factor solution was favoured over the alternative sixfactor solution (Glick and Fiske 1999) to aid comparability with the vast majority of cross-cultural studies which use the AMI. The factorial solutions largely confirmed the original HM and BM factors. Factorial, or metric, invariance was formally tested and supported with Tucker's (1951) phi coefficient of congruence. The phi values indicated that Polish and

Table 2 Invariance analysis: results of factor analyses with Varimax rotation and forced two-factor extraction along with Cronbach's Alpha Reliability Coefficients and Tucker's Factor Congruity phi Coefficients in South Africa (SA), Poland (PL) and the United Kingdom (UK)

Items (and the scale they originally belonged to as in Glick and Fiske 1999)

\begin{tabular}{|c|c|c|c|c|}
\hline A toadings & \multicolumn{2}{|c|}{ PL loadings } & \multicolumn{2}{|c|}{ UK loadings } \\
\hline BM & HM & $\mathrm{BM}$ & HM & $\mathrm{BM}$ \\
\hline .645 & & .694 & & .644 \\
\hline & .396 & & .434 & \\
\hline
\end{tabular}

1. Even if both members of a couple work, the woman ought to be more attentive to taking care of her man at home. (BM)

2. A man who is sexually attracted to a woman typically has no morals about doing whatever it takes to get her in bed. (HM)

3. Men are less likely to fall apart in emergencies than women are. (BM)

4. When men act to "help" women, they are often trying to prove they are better than women. (HM)

5. Every woman needs a male partner who will cherish her. (BM)

6. Men would be lost in this world if women weren't there to guide them. (HM)

7. A woman will never truly be fulfilled in life if she doesn't have a committed, long term relationship with a man. (BM)

8. Men act like babies when they are ill. (HM)

9. Men always fight to have greater control in society than women. (HM)

10. Men are mainly useful to provide financial security for women. (BM)

11. Even men who claim to be sensitive to women's rights really want a traditional relationship at home, with the woman performing most of the housekeeping and childcare. (HM)

12. Every woman ought to have a man she adores. (BM)

13. Men are more willing to put themselves in danger to protect others. (BM)

14. Men usually try to dominate conversations when talking to women. (HM)

15. Most men pay lip service to equality for women, but can't handle having a woman as an equal. (HM)

16. Women are incomplete without men. (BM) 
19. Most men sexually harass women, even if only in subtle ways, once they are in position of power over them. (HM)

20. Women ought to take care of their men at home, because men would fall apart if they had to fend for themselves. (BM)

$\%$ if Variance

Tucker's phi (coefficient of factor congruity with UK factors)

Reliability (after item 20 removed)

.586

.352

.460

.504

.501

Loadings below . 30 were suppressed. The meaning of the abbreviations is as follows: PL Poland, SA South Africa, UK United Kingdom, HM Hostility to Men, BMBenevolence to Men 
South African factors where highly similar to the British ones exceeding even the most conservative cut off point of .95 (Van de Vijver and Poortinga 1994). In order to improve metric invariance, item 20 was removed from all later analyses as it loaded substantively (above .45 ) on an opposite factor (i.e., HM instead of BM) in Poland and in South Africa, and equally strongly on both factors in the United Kingdom. See Table 2 for relevant factor loadings, phi and precise Cronbach's alpha coefficients as well as the items' wording.

The Hostility toward Men subscale (HM) was used to capture hostile gender attitudes toward men. This consisted of ten items. Scores were obtained by averaging responses to individual items. The higher the average score, the higher an

individual's hostility to men. Reliability scores reported by

Glick and Fiske (1999) ranged between .81 and .86. Similar satisfactory Cronbach Alpha scores emerged for each country in the current study: $\alpha_{\mathrm{UK}} 0.81 ; \alpha_{\mathrm{PL}} 0.71 ; \alpha_{\mathrm{SA}} 0.80$.

The Benevolence toward Men subscale (BM) was used to capture benevolent gender attitudes toward men. This consisted of nine items, (after item 20 was removed as explained above). Again, scores were obtained by averaging responses to individual items and, thus, the higher the average score, the higher an individual's benevolence to men. Reliability coefficients reported by Glick and Fiske (1999) ranged between .79 and .83. Cronbach Alpha scores emerging in the current study were also satisfactory: $\alpha_{\mathrm{UK}} 0.84 ; \alpha_{\mathrm{PL}} 0.85 ; \alpha_{\mathrm{SA}} 0.80$.

\section{Results}

In order to avoid Type I error, multivariate analysis of variance (MANOVA) for both measures of attitudes to men (HM and BM) was conducted by country and gender. As Table 3 illustrates, participants' mean scores ranged from a minimum of 1.79 to a maximum of 3.08. Given that the possible range is 0 (no endorsement) to 5 (complete endorsement), in absolute terms this indicates relatively low endorsement of ambivalent attitudes in the three samples. The multivariate test statistic using Pillai's trace indicated that there were significant main effects of country, V0.11, F $(4,1076) 015.17, \mathrm{p}<.001$, gender, $\mathrm{V} 0.21, \mathrm{~F}(2,537) 069.95$, $\mathrm{p}<.001$, and country $\mathrm{x}$ gender interaction, $\mathrm{V} 0.10, \mathrm{~F}(4$, $1076014.21, \mathrm{p}<.001$, on both types of attitudes. Separate univariate ANOVAs on the outcome variables are reported below in an order consistent with the hypotheses. Descriptive statistics are reported in Table 3.
Table 3 Means and standard deviations for three countries and two gender groups for hostile and benevolent attitudes toward men

\begin{tabular}{|c|c|c|c|c|c|c|}
\hline \multirow[t]{2}{*}{ Measure } & \multicolumn{3}{|c|}{ Hostility } & \multicolumn{3}{|c|}{ Benevolence } \\
\hline & M & SD & $\mathrm{n}$ & M & SD & $\mathrm{n}$ \\
\hline \multicolumn{7}{|c|}{ United Kingdom } \\
\hline Females & $2.33^{\mathrm{a}}$ & .09 & 78 & $1.95^{\mathrm{a}}$ & .98 & 78 \\
\hline Males & $1.79^{\mathrm{b}}$ & .09 & 87 & $2.00^{\mathrm{a}}$ & 1.03 & 87 \\
\hline \multicolumn{7}{|l|}{ Poland } \\
\hline Females & $2.30^{\mathrm{a}}$ & .08 & 101 & $2.11^{\mathrm{a}}$ & .87 & 101 \\
\hline Males & $2.40^{\mathrm{a}}$ & .09 & 88 & $2.90^{\mathrm{c}}$ & .94 & 88 \\
\hline \multicolumn{7}{|c|}{ South Africa } \\
\hline Females & $3.08^{c}$ & .10 & 70 & $2.02^{\mathrm{a}}$ & .86 & 70 \\
\hline Males & $2.21^{\mathrm{a}}$ & .07 & 119 & $2.81^{\mathrm{c}}$ & 1.02 & 11 \\
\hline
\end{tabular}

Scale endpoints for both Hostile and Benevolent attitude scales were 0 (disagree strongly) and 5 (agree strongly). The higher the score the higher level of hostility or benevolence respectively. Means with different superscripts within a column are significantly different at $\mathrm{p}<05$ 


\section{Comparison of Three Countries on Benevolent and Hostile} Attitudes to Men

Hypothesis 1a predicted that South African participants would be more hostile to men than those in Poland, whilst individuals in the United Kingdom would be less hostile than both.
This was tested with a main effect of country on HM and confirmed. The follow-up analysis for the significant main country effect on HM, F(2,543)022.27, $\mathrm{p}<.001, \mathrm{p}^{2} 0.076$, revealed that, indeed, whilst both the British (M02.06) and Polish (M02.35) respondents rated significantly lower than South African ones (M02.64, $\mathrm{p}<.001$ and $\mathrm{p}<.05$ respectively), the British and Polish samples also differed significantly $(\mathrm{p}<.01)$. That is, all countries were aligned along a continuum of hostile attitudes with the United Kingdom being least hostile and South Africa most hostile as predicted.

Hypothesis $1 \mathrm{~b}$ predicted a similar pattern for BM (South African participants scoring highest and Polish lowest) and this was partially confirmed by the test of main country effect. The follow-up for the significant main country effect on BM, F(2,543) 014.63, $\mathrm{p}<.001, \mathrm{y}_{\mathrm{p}}^{2} 0.052$, indicated that Polish (M02.50) and South African (M02.41) samples both rated significantly higher on BM than the British sample (M01.98, both $\mathrm{p}<.001$ ) whilst Poland and South Africa did not differ significantly from each other (p0.379). Thus, with regard to BM, the continuum was somewhat shortened, with both Poland and South Africa occupying the more conservative spectrum opposite the more liberal United Kingdom.

\section{Testing Gender Differences across Countries}

Hypothesis 2a predicted that the gender gap, where women outscore men on hostile attitudes, will emerge for South Africa. Hypothesis $2 b$, on the other hand, stated that women will underscore men on benevolent attitudes in this country. These predictions were tested with gender $\mathrm{x}$ country interaction effects. While the analysis revealed that women generally scored higher on HM (M02.57) than men (M02.13), $\mathrm{F}(1,543) 038.92, \mathrm{p}<.001, \mathrm{y}_{\mathrm{p}}^{2} 0.070$, and 
lower on BM (M02.03) than men (M02.57), F(1,543)041.96, p $<.001, \mathrm{y}^{2} \quad$ Q.072, these main effects were indeed qualified by complex country $\mathrm{x}$ gender interaction effects. These emerged for both HM, F(2,543)017.24, $\mathrm{p}<.001, \mathrm{y}_{\mathrm{p}}^{2} 0.060$, and BM, $F(2,543) 08.16, p<.001, \eta^{2} 0.029$. As will be seen below, their nature was as expected for BM (H2b - confirmed) and for HM (H2a - confirmed) in South Africa. Interesting findings emerged also for United Kingdom and Poland (see

Table 2).

A follow-up analysis, with one-tailed independent t tests, was conducted within each country on HM. It revealed significant differences between women and men for the United Kingdom and South Africa, t(163)04.06, $\mathrm{p}<.001$ and $\mathrm{t}(187) 06.66, \mathrm{p}<.001$ (respectively), but not for Poland, $\mathrm{t}$ (188)0-.99, p 0.322. Both British and South African women scored higher on $\mathrm{HM}\left(\mathrm{M}_{\mathrm{UK}} 02.33\right.$ and $\left.\mathrm{M}_{\mathrm{SA}} 03.08\right)$ than men in these countries $\left(\mathrm{M}_{\mathrm{UK}} 01.79\right.$ and $\mathrm{M}_{\mathrm{SA}} 02.21$-see Fig. 1). Thus Hypothesis 2a, that a gender gap would exist in South Africa, was confirmed. A similar significant gender gap was somewhat surprisingly also observed in the United Kingdom. No significant gender gap emerged in Poland.

Similar follow-up analyses with one-tailed independent tests were conducted within each country on BM and revealed a different pattern from the one obtained on HM scores (see Fig. 2). That is, consistent with H2b, men scored higher on BM than women in South Africa $\left(\mathrm{M}_{\mathrm{M}} 02.81\right.$ vs. $\mathrm{M}_{\mathrm{W}}$ 02.02), $\mathrm{t}(164.91) 0-5.66, \mathrm{p}<.001$. Gender differences in $\mathrm{BM}$ did not emerge in the United Kingdom, t(163)0-.35, p 0.726 . However, in Poland, a gender gap of the same nature as in South Africa was revealed $\left(\mathrm{M}_{\mathrm{M}} 02.89\right.$ vs. $\left.\mathrm{M}_{\mathrm{W}} 02.11\right)$, $\mathrm{t}(188) 0-5.94, \mathrm{p}<.001$.

\section{Discussion}

The main aim of this study was to address the gap in crosscultural research concerning the nature of sexism. We did so

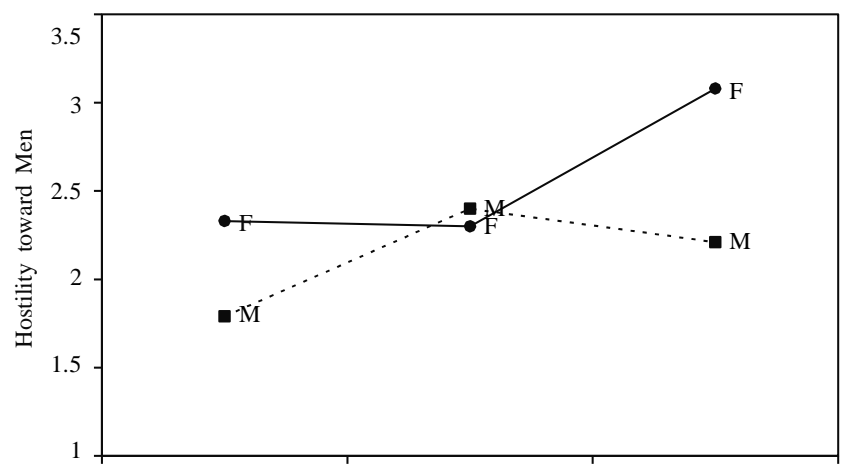

UK

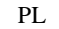

SA

Fig. 1 Hostility toward men as a function of country and participants' gender gender

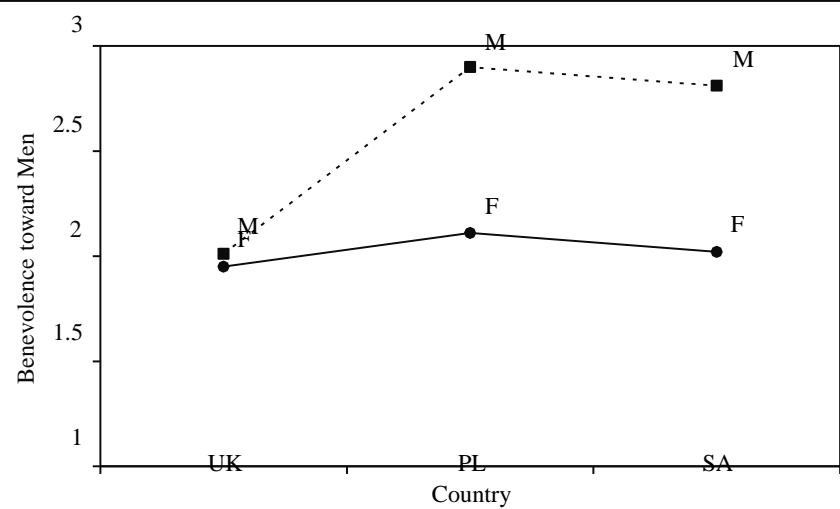

Fig. 2 Benevolence toward men as a function of country and participants' gender

by testing student attitudes toward men in two underresearched countries under transition, Poland and South Africa, and comparing them to gender attitudes in more heavily researched, gender-egalitarian long-standing democracy of the United Kingdom. Two key research questions were posed: (1) How do these countries compare on benevolent and hostile attitudes toward men, and (2), How do men compare to women in terms of attitudes toward men within each of the three countries? Answers are discussed below.

\section{The Nature of Sexist Attitudes toward Men in Poland, South} Africa, and the United Kingdom

Based on analysis of the countries' socio-political context, the AST and overview of previous research it was hypothesized that British participants would be most liberal, followed by Polish and South African participants in terms of both types of attitudes toward men. Our findings largely supported these predictions. The expected pattern of differences emerged for hostile attitudes. However, Polish and South African participants were equally benevolent to men and significantly more so than in the United Kingdom. This lack of significant differences on BM between Poland and South Africa, though not expected, is consistent with AST's notion that in more hostile-sexist countries there is the need to 'sweeten' reality with more evaluatively positive BM. That is to say, BM rationalizes the gender differences in status and makes them easier to accept, and in so doing maintains the status quo (Glick et al. 2004). The significant difference between scores from South Africa and the United Kingdom provide further support for the relative genderconservatism of the South African sample and genderegalitarianism of the British sample. It also resonates with

the socio-political profile of each country, where values of equality are well established in the old democracy of the United Kingdom, but still struggle against the legacy of deeply rooted inequality in South Africa. 
The somewhat inconsistent results from Poland, which occupies a moderate position on hostility but a rather conservative one on benevolence, may be explained by: (a) the need to reject the enforced emancipation of communism as well as the dissatisfaction with the re-masculinisation of the new capitalism as seen in scores on hostility to men, and (2) the related need to return to femininity (LaFont 2001; Yakushko 2005) as seen in scores on benevolence to men. Further studies could fruitfully test these possibilities directly.

As argued earlier, the emerging cross-cultural pattern is not necessarily shared equally by men and women within each of the three countries.

\section{Gender Gap in Attitudes to Men across the Three Countries}

As predicted, the main gender effects reported in the literature, where women score higher than men on HM but lower then men on BM (Glick et al. 2004), were qualified by interactions between country and gender. Indeed, the prediction of women's greater (than men's) hostility to men held for the most gender-conservative South Africa (in line with H2a). This confirms AST's contention that the higher the gender conservatism, the more reasons for women to be hostile toward men. However, unexpectedly, the same pattern also held for the most egalitarian United Kingdom. This finding also contradicts earlier observations reported by Glick et al. (2004) for this country. Thus, despite United Kingdom's relative gender liberalism, British women still seem to resent male power. It is possible that this very resentment has a preventive function and is a reaction to the observed slowdown in egalitarian trends (Blau et al. 2006; Dorius and Alwin 2010; Scott 2006) and the reported threat of return to sexism (Braun and Scott 2009; Crompton et al. 2005; Walter 2010). Although the United Kingdom scores amongst the most egalitarian countries, a gender gap in wages of $19.8 \%$ was still reported in 2010 by the Office for National Statistics ("Office for National Statistics" 2011). This reflects a drop from $22 \%$ in 2009-the biggest since 1997. However, in terms of equal pay, the United Kingdom's ranking was 81st out of 130 countries in 2008 and its overall gender equality worldwide ranking fell from 9th position in 2006 to 13th in 2008 (Zahidi and Ibarra 2010). Thus, British women may embrace hostile attitudes to men in an attempt to protect relative gender-egalitarianism and prevent the return of sexism.

With regard to BM, hypothesis H2b was confirmed: Women's lower (than men's) endorsement of BM held for South Africa. Such a gender gap did not emerge in the United Kingdom-a finding which is consistent with Glick et al. (2004). Taken together, these findings are congruent with the theoretical argument of in-group favouritism. According to Glick et al. (2004), men, particularly in more gender-conservative countries (such as South Africa and, perhaps, Poland here), should be especially motivated to endorse benevolent beliefs as they act to maintain the subordinate position of women. For example, admitting that men need women's care rewards women for taking on traditional maternal and serving roles even though it confirms men's weaknesses. The lack of the gender gap in the United Kingdom may be due to fewer tensions, and therefore greater agreement, between men and women in more gender-egalitarian countries-at least with regard to benevolent forms of sexism.

The Polish sample was the only one of the three where no gender gap was detected on HM. This also diverges from the general cross-cultural pattern detected by Glick et al. (2004), where women outscored men on HM. However, the gender gap on BM was similar to the one found in South Africa, where Polish men outscored Polish women on benevolence to men. The unique character of Polish transition may be responsible for these findings. Women's lower scores on hostility to men may reflect the rejection of feminism. It should be noted that HM is not a form of feminism as, unlike feminism, it serves to maintain rather than challenge the status quo (Glick et al. 2004; Glick et al. 2002). Yet expressing hostility to men and resentment of their power may be perceived as feminist sentiments. Polish women may be particularly reluctant to express such attitudes because of the historic associations of feminism with communism and its enforced emancipation. Indeed, it is argued that legalization of emancipation in Poland did not equate to the actual emancipation of women and, in fact, stifled the development of feminism in Poland (Ksiniewicz 2004). For example, Polish women were encouraged to join the workforce but were not given the opportunity to advance their career on equal terms with men. This artificial emancipation placed triple burden on women's shoulders: the requirement to be a good mother, employee and social activist (LaFont 2001). Some theorists also attribute negative attitudes to feminism in Poland to other historical factors. In the second half of the 18th century Poland underwent prolonged partition and ceased to exist as a country for 122 years. It is argued that the only way in which the Poles could maintain their national identity was via an emphasis on family and Polish tradition (Rosner 1997). The idealized image of 'Matka Polka' - directly translated as the 'Mother Pole'promoted at that time required women's full commitment to family as an expression of support for Polish national identity and fight for independence. Any feminist sentiments, which are based on the betterment of the individual (read 'women' in this instance) rather than on the good of the country, were perceived as the betrayal of the Polish cause (Ksiniewicz 2004). Since benevolence toward men does not appear feminist, and by association communist, Polish women were not inhibited from expressing BM. However, 
this pattern of findings differs from the one found in Ukraine, the only other Eastern European country where ambivalence to men was measured. Yakushko (2005) reported higher hostility in female students compared to male students but no gender differences on BM. This finding is complicated by the fact that, unlike here, AMI was administered to Ukrainian students in English instead of their native language. Thus, more studies are needed to test our post hoc explanation directly and to determine whether our findings are unique to Poland or shared by other Eastern European countries.

The gender gap pattern found on HM in the South African and in the British samples is typically found in other countries (Glick et al. 2004). The pattern found in Poland, being almost a mirror image of the two other countries, is unusual. However, taken together with the scores on BM, the different attitudinal patterns emerging in each country can still serve important social functions-including system justificationeven though not always in the way predicted by AST. Specifically, the traditional explanation proposed by Glick et al. (2004) seems to apply especially in the case of South Africa. That is, women's hostility to men is indicative of female resentment of male hostility toward them (Glick et al. 2000). In such cases, it is in men's in-group interest to reject such a belief, which is seen in their lower (than women's) scores on $\mathrm{HM}$ and higher scores on BM. This may be a particularly adaptive strategy in countries such as South Africa, where the transition to democracy represents a response to previous severe inequality, and embraces values of gender equality sufficiently so as to allow women to express hostile sexism freely. Men's low hostility to men, and emphasis on their own benevolence, may appear in step with the democratic emphasis on equality in contemporary South Africa. For females, on the other hand, higher hostility and lower benevolence toward men is in keeping with the spirit of fighting for their equality.

In Poland, however, expressing hostility to men may be socially stigmatized as indicative of feminism and thus, by association, of enforced emancipation under communism (LaFont 2001). In such case, system justification has to rest solely on the benevolent elements of sexism because of their greater acceptability. Indeed, Polish men embrace benevolent set of beliefs more than women. By taking such a position, men may attempt to reward those women who comply with this benevolent image (that is, those who do attend to their needs and care for them). At the same time, they can withdraw reward from those women who fail to comply with it (Glick and Fiske 2001a; Glick et al. 2004; Viki and Abrams 2004). Thus, it is possible that $\mathrm{BM}$ allows Polish men to maintain the status quo without being accused of communist sentiments. On the part of Polish women, low benevolence to men may be the only acceptable, and historically adaptive, way of expressing discontent with the status quo without the risk of encouraging another era of enforced emancipation.
In the liberal United Kingdom, where women are less dependent on men, endorsing benevolent beliefs may have little regulatory use for men. Firm rejection of hostile attitudes and low endorsement of benevolent attitudes among men are indicative of their relatively liberal and sexism-free attitudes. In this case, women's higher then men's hostility toward men may serve the function of guarding against (the return of) sexism and thus maintaining egalitarianism, rather than reacting to the men's hostility to women as per the original explanation proposed by Glick et al. (2004) and evident in the South Africa above. Thus, egalitarian gender attitudes may be maintained by women's hostility to men. Further research is required to explicitly explore the possible, and culturally varied, mechanisms of maintaining and challenging the status quo.

There are two limitations to the generalisability of our findings. First is the choice of student samples. Whilst it is common practice (in fact, the majority of the studies reviewed here used mostly student samples) and thus helps to increase comparability across countries, it compromises the generalisability of the findings outside the student population. It is likely that the relative gender egalitarianism of our samples, where most scores fall below the scale midpoint of 3.00, is greater than that of other, older or less educated, social groups from the respective countries (Dorius and Alwin 2010; Scott 2006; Swim et al. 2005). Thus, further research could fruitfully improve the current understanding of crosscultural gender attitudes by testing individuals from various walks of life. This is particularly relevant to South Africa, arguably, the most diverse country of the three examined here.

Second, although the most recent scales of attitudes toward men were used here, these were still self-report measures, which are prone to social desirability effects, and thus may have returned optimistically liberal scores. Although their improved psychometric properties are generally recognized (Swim et al. 2005), they are nonetheless criticized for being too overt and insufficiently sensitive (Nelson 2002) an issue mainly for the egalitarian United Kingdom. Although we have used a cover story with the aim of preventing social desirability effects, the use of implicit measures of gender attitudes (e.g., the Implicit Associations Test, Greenwald and Banaji 1995; Lane et al. 2007; Rudman and Kilianski 2000) could be employed in future investigations and compared cross-nationally to the scores on explicit tools in order to address this issue directly. Furthermore, the two underresearched countries here both happen to be undergoing socio-economic transition and were compared to a single example of well-established democracy. In order to better understand the nature of attitudes to men in countries undergoing transition, more such countries need to be included in future investigations. This could also be fruitfully accompanied by similar investigations into hostile and benevolent attitudes toward women, an important component of sexist gender role ideology (Glick and Fiske 1996). 
Conclusion

This research was conducted in order to address the gap in the cross-cultural literature on attitudes toward men, particularly in under-researched countries which may be described as 'societies in transition'. This was achieved by examining hostile and benevolent attitudes toward men in student samples from two such countries, Poland and South Africa, and by comparing them to student samples from the gender-egalitarian and wellestablished democracy of the United Kingdom. This study has added to our current body of knowledge by comparing these three countries directly for the first time and by emphasizing that the emerging pattern of findings depends upon socio- political context, on the type of attitudes (i.e., benevolent vs. hostile), and is qualified by interactions between country and gender. Our work also suggests that hostile and benevolent attitudes may serve more than the one function of system justification and that there might be more than one way to maintain the status quo, which may be dependent on culture - a possibility which awaits further investigation.

Acknowledgments We would like to thank Prof. Irene Frieze, four anonymous reviewers, and Dr David Giles for their insightful and useful comments on earlier versions of this manuscript. We would also like to thank the University of Winchester for sponsoring this research through a Research and Knowledge Transfer Grant.

\section{Appendix}

Table 4 Translation of Glick and Fiske’s (1999) Ambivalence to Men Inventory into Polish and back-translation into English

Item No Polish translation $\quad$ Back-translation from Polish to English

1. Nawet jeśli oboje partnerzy pracują kobieta powinna bardziej troszczyć się w domu o swojego mężczyznę.

2. Mężczyzna, który pożąda seksualnie kobiety zwykle nie na skrupułów i zrobi wszystko, żeby zaciągnąć ją do łóżka.

3. Mężczyźni prawdopodobnie rzadziej załamują się w sytuacjach kryzysowych niż kobiety.

4. Kiedy mężczyźni robią coś, żeby “pomóc” kobietom często próbują udowodnić że są lepsi niż kobiety.

5. Każda kobieta potrzebuje partnera-mężczyzny, który otoczy ją czułą opieką.

6. Mężczyźni zagubiliby się w tym świecie gdyby nie było kobiet, które nimi kierują.

7. Kobieta nigdy nie będzie całkowicie spełniona jeżeli nie będzie w stałym stabilnym związku z mężczyzną.

8. Mężczyźni zachowują się jak niemowlęta kiedy są chorzy.

9. Mężczyźni będą zawsze walczyć aby mieć większą władzę w społeczeństwie niż kobiety.

10. Mężczyźni są głównie przydatni aby zapewnić kobietom bezpieczeństwo finansowe.

11. Nawet mężczyźni, którzy deklarują wrażliwość w kwestii praw kobiet w rzeczywistości w domu chcą tradycyjnego związku, gdzie kobieta wykonuje większość domowych prac i opiekuje się dziećmi.

12. Każda kobieta powinna mieć mężczyznę, którego uwielbia.

13. Mężczyźni są bardziej skłonni narażać się na niebezpieczeństwo, żeby ochraniać innych.

14. Mężczyźni zwykle próbują dominować w rozmowach z kobietami.

15. Większość mężczyzn składa gołosłowne deklaracje o równouprawnieniu kobiet, jednak nie potrafią odnaleźć się w sytuacji w których kobiety są im równe.
Even if both partners work, it is the woman who should take greater care for her man at home.

A man who is sexually attracted to a woman usually does not have any scrupules and would do anything to get her in bed.

Men usually break down more seldom in crisis then do women.

When men do things with the aim to 'help' women they normally are trying to prove that they are better than women.

Every woman needs a male partner who will care tenderly for her.

Men would get lost in this world if there were no women to guide them.

A woman will never be completely fulfilled if she does not have a commited, long-term relationship with a man.

Men behave like babies when they are ill.

Men will always fight for greater power in society than women.

Men are mainly useful in providing financial security for women.

Even those men who say they are sensitive to women's rights, in reality want traditional relationship at home where women do most housework and care for children.

Every woman should have a man she adores.

Men are more willing to put themselves in danger to protect others.

Men normally try to dominate in conversations with women.

Most men declare that they support women's equality but cannot deal with situations when women are equal to them. 
16.

Kobiety bez mężczyzn są niepełne.

17.

Ogólnie rzecz biorąc, większość mężczyzn jest jak dzieci.

Mężczyźni podejmuja ryzyko chetniej niż kobiety.
Women are incomplete without men.

Generally speaking, most men are like children really.

Men take risks more willingly than women. 
Table 4 (continued)

\begin{tabular}{lll}
\hline Item No & Polish translation & Back-translation from Polish to English \\
\hline 19. & $\begin{array}{c}\text { Większość mężczyzn napastuje kobiety seksualnie, nawet jeśli } \\
\text { robią to w subtelny sposób, jeżeli zajmą pozycję która daje im } \\
\text { władzę nad kobietami. }\end{array}$ & $\begin{array}{c}\text { Most men sexually harass women, even if subtly, once they find } \\
\text { themselves in a position of power over women. }\end{array}$ \\
$\begin{array}{l}\text { Kobiety powinny w domu opiekować się swoimi mężczyznami, } \\
\text { ponieważ mężczyźni załamaliby się gdyby mieli sami dawać } \\
\text { sobie radę. }\end{array}$ & $\begin{array}{c}\text { Women should take care of their men at home as men would } \\
\text { break down if they were to look after themselves on their own. }\end{array}$ &
\end{tabular}

\section{References}

Becker, J. C. (2010). Why do women endorse hostile and benevolent sexism? The role of salient female subtypes and internalization of sexist contents. Sex Roles, 62, 453-467. doi:10.1007/s11199-0099707-4.

Ben-Porath, Y. S. (1990). Cross-cultural assessment of personality: The case for replicatory factor analysis. In J. N. Butcher \& C. D. Spielberger (Eds.), Advances in personality assessment (Vol. 8, pp. 27-48). Mahwah: Lawrence Erlbaum Associates.

Bhana, A., Zimmerman, R., \& Cupp, P. (2008). Gender role attitudes and sexual risk among adolescents in South Africa. Vulnerable Children and Youth Studies, 3, 112-119. doi:10.1080/ 17450120701867546.

Blau, F. D., Brinton, M. C., \& Grusky, D. B. (2006). The declining significance of gender? New York: Russell Sage.

Boski, P., Chojnowska, M., \& Koziej, J. (2007). Kultura i tożsamość rodzaju: porównania polsko-włoskie i polsko-niemieckie [Culture and gender identity: Polish-Italian and Polish-German comparison]. Psychological Studies, 45(2), 5-20.

Braun, M., \& Scott, J. (2009). Gender-role egalitarianism-is the trend reversal real? International Journal of Public Opinion Research, 21, 362-367. doi:10.1093/ijpor/edp032.

Crompton, R., Brockmann, M., \& Lyonette, C. (2005). Attitudes, women's employment and the domestic division of labour: A cross-national analysis of two waves. Work, Employment \& Society, 19, 213-233. doi:10.1177/0950017005053168.

Dodoo, F. N., \& Frost, A. E. (2008). Gender in African population research: The fertility/reproductive health example. Annual Review of Sociology, 34, 431-451. doi:10.1146/annurev. soc.34.040507.134552.

Dorius, S. F., \& Alwin, D. F. (2010). The global development of egalitarian beliefs - a decomposition of trends in the nature and structure of gender ideology. Ann Arbor: Population Studies Centre Research Report, University of Michigan, Institute for Social Research.

England, P. (2006). Toward gender equality: Progress and bottlenecks. In F. D. Blau, M. C. Brinton, \& D. B. Grusky (Eds.), The declining significance of gender? (pp. 245-264). New York: Russell Sage.

Forbes, G. B., Doroszewicz, K., Card, K., \& Adams-Curtis, L. (2004). Association of the thin body ideal, ambivalent sexism, and selfesteem with body acceptance and the preferred body size of college women in Poland and the United States. Sex Roles, 50, 331-345. doi:10.1023/B:SERS.0000018889.14714.20.

Frieze, I. H., Ferligoj, A., Kogovsek, T., Rener, T., Horvat, J., \& Sarlija, N. (2003). Gender-role attitudes in university students in the United States, Slovenia, and Croatia. Psychology of Women Quarterly, 27, 256-261. doi:10.1111/1471-6402.00105.

Gibbons, L. J., Stiles, D. A., \& Shokodriani, G. M. (1991). Adolescents" attitudes toward family and gender roles: An international comparison. Sex Roles, 25, 625-643. doi:10.1007/BF00289568.

Glick, P. (2004). The other side of the coin: Ambivalence toward men and gender inequality. A comment on Viki (2004). Social Psychological Review, 6(2), 89-92.

Glick, P., \& Fiske, S. T. (1996). The ambivalent sexism inventory: Differentiating hostile and benevolent sexism. Journal of Personality and Social Psychology, 70, 491-512. doi:10.1037/00223514.70.3.491.

Glick, P., \& Fiske, S. T. (1999). The ambivalence toward men inventory: Differentiating hostile and benevolent beliefs about men. Psychology of Women Quarterly, 23, 519-536. doi:10.1111/ j.1471-6402.1999.tb00379.x.

Glick, P., \& Fiske, S. T. (2001a). An ambivalent alliance: Hostile and benevolent sexism as complementary justifications for gender inequality. American Psychologist, 56(2), 109-118. doi:10.1037/ 0003-066X.56.2.109.

Glick, P., \& Fiske, S. T. (2001b). Ambivalent sexism. In M. P. Zanna (Ed.), Advances in experimental social psychology. Vol.33 (pp. 115-188). San Diego: Academic.

Glick, P., Fiske, S. T., Mladinic, A., Saiz, J. L., Abrams, D., \& Masser, B. (2000). Beyond prejudice as simple antipathy: Hostile and benevolent sexism across cultures. Journal of Personality and Social Psychology, 79, 765-775. doi:10.1037/0022-3514.79.5.763.

Glick, P., Lameiras, M., \& Castro, Y. R. (2002). Education and Catholic religiosity as predictors of hostile and benevolent sexism toward women and men. Sex Roles, 47, 433-441. doi:10.1023/ A:1021696209949.

Glick, P., Fiske, S. T., Masser, B., Manganelli, A. M., Huang, L., Castro, Y. R., et al. (2004). Bad but bold: Ambivalent attitudes toward men predict gender inequality in 16 nations. Journal of Personality and Social Psychology, 86, 713-728. doi:10.1037/ 0022-3514.86.5.713.

Greenwald, A. G., \& Banaji, M. R. (1995). Implicit social cognition: Attitudes, self-esteem, and stereotypes. Psychological Review, 102, 4-27. doi:10.1037/0033-295X.102.1.4.

Hassim, S. (2002). “A conspiracy of women”: The women's movement in South Africa's transition to democracy. Social Research, 69, 693-732.

Hassim, S. (2005). Nationalism displaced: Citizenship discourses in transition. In A. Gouws (Ed.), (Un)thinking citizenship: Feminist debates in contemporary South Africa (pp. 55-69). Cape Town: University of Cape Town Press.

Inglehart, R., \& Norris, P. (2003). Introduction: Explaining the rising tide of gender equality. In R. Inglehart \& P. Norris (Eds.), Rising 
tide: Gender equality and cultural change around the world (pp. 1-28). Cambridge: Cambridge University Press.

Ksiniewicz, M. (2004). Specyfika polskiego feminizmu. [Specificity of Polish feminism]. Kultura i Historia, 6, 90-100.

LaFont, S. (2001). One step forward, two steps back: Women in the post-communist states. Communist and Post-Communist Studies, 34, 203-220. doi:10.1016/S0967-067X(01)00006-X.

Lane, K. A., Banaji, M. R., Nosek, B. A., \& Gereenwald, A. G. (2007). Understanding and using the Implicit Association Test: IV. In B. Wittenbrink \& N. Schwartz (Eds.), Implicit measures of attitudes (pp. 59-102). London: The Guilford Press.

Levant, R. F., Richmond, K., Sellers, A., Mitina, O., Cuthbert, A., Mateveev, A., et al. (2003). Masculinity ideology among Russian and U.S. young men and women and its relationship to unhealthy lifestyle habits among young Russian men. Psychology of Men \& Masculinity, 4, 26-36. doi:10.1037/1524-9220.4.1.26.

Lewicka, M. (2005). Polacy są wielkim i dumnym narodem, czyli nasz portret (wielce) zróżnicowany. [Poles are a great and proud nation, i.e., a (very) diverse portrayal of ours]. In M. Drogosz (Ed.), Jak Polacy Przegrywają Jak Polacy Wygrywają? (pp. 5-35). Gdańsk: Gdańskie Wydawnictwo Psychologiczne.

Luyt, R. (2005). The Male Attitude Norms Inventory-II: A measure of masculinity ideology in South Africa. Men \& Masculinities, 8, 208-229. doi:10.1177/1097184X04264631.

Luyt, R. (2011). Representation of gender in South African Television Advertising: A content analysis. Sex Roles, 65, 356-370. doi:10.1007/s11199-011-0027-0.

Mantell, J. E., Needham, S. L., Smit, J. A., Hoffman, S., Cebekhulu, Q., Adams-Skinner, J., et al. (2009). Gender norms in South Africa: Implications for HIV and pregnancy prevention among African and Indian women students at a South African tertiary institution. Culture, Health \& Sexuality, 11, 139-157. doi:10.1080/13691050802521155.

McDaniel, A. E. (2008). Measuring gender egalitarianism: The attitudinal differences between men and women. International Journal of Sociology, 38(1), 58-80. doi:10.2753/IJS0020-7659380103.

Nelson, T. D. (2002). The psychology of prejudice. Upper Saddle River: Prentice Hall.

Office for National Statistics. (2011). Patterns of pay: Results of the Annual Survey of Hours and Earnings, 1997 to 2010. Retrieved from http://www.ons.gov.uk/ons/index.html.

Olson, J., Frieze, I., Wall, S., Zdaniuk, B., Ferligoj, A., Kogovšek, T., et al. (2007). Beliefs in equality for women and men as related to economic factors in Central and Eastern Europe and the United States. Sex Roles, 56, 297-308. doi:10.1007/s11199-006-9171-3.

Pollert, A. (2003). Women, work and equal opportunities in postcommunist transition. Work, Employment \& Society, 17, 331357. doi:10.1177/0950017003017002006.

Robila, M., \& Krishnakumar, A. (2004). The role of children in Eastern European families. Children \& Society Volume, 18, 30-41. doi:10.1002/chi.773

Rosner, K. (1997). Czy istnieje w Polsce ruch feministyczny? [Does the feminist movement exist in Poland?]. Pelnym Glosem, 5, 1327.

Rudman, L. A., \& Kilianski, S. E. (2000). Implicit and explicit attitudes towards female authority. Personality and Social Psychology Bulletin, 26, 1315-1328. doi:10.1177/0146167200263001.

Scott, J. (2006, September). Family and gender roles: How attitudes are changing (GeNet Working Paper No. 21). Cambridge, UK.

Seguino, S. (2007). PlusÇa change? Evidence on global trends in gender norms and stereotypes. Feminist Economics, 13(2), 128. doi:10.1080/13545700601184880.
Shafiro, M. V., Himelein, M. J., \& Best, D. L. (2003). Ukrainian and U.S. American females: Differences in individualism/collectivism and gender attitudes. Journal of Cross-Cultural Psychology, 34, 297-303.

Shefer, T., Crawford, M., Strebel, A., Simbayi, L. C., Dwadwa-Henda, N., Cloete, A., et al. (2008). Gender, power and resistance to change among two communities in the Western Cape, South Africa. Feminism \& Psychology, 18, 157-182. doi:10.1177/ 0959353507088265.

Sibley, C. G., \& Wilson, M. S. (2004). Differentiating hostile and benevolent sexist attitudes toward positive and negative sexual female subtypes. Sex Roles, 51, 687-696. doi:10.1007/s11199-004-0718-x.

Sibley, C. G., Overall, N. C., \& Duckitt, J. (2007). When women become more hostilely sexist toward their gender: The systemjustifying effect of benevolent sexism. Sex Roles, 57, 743-754. doi:10.1007/s11199-007-9306-1.

Swim, J. K., Aikin, K. J., Hall, W. S., \& Hunter, B. A. (1995). Sexism and racism: Old-fashioned and modern prejudices. Journal of Personality and Social Psychology, 68, 199-214. doi:10.1037/ 0022-3514.68.2.199.

Swim, J. K., Mallet, R., Russo-Devosa, Y., \& Stangor, C. (2005). Judgments of sexism: A comparison of the subtlety of sexism measures and sources of variability in judgments of sexism. Psychology of Women Quarterly, 29, 406-411. doi:10.1111/ j.1471-6402.2005.00240.x.

Tougas, F., Brown, R., Beaton, A. M., \& Joly, S. (1995). Neosexism: Plus ça change, plus c'est pareil. Personality and Social Psychology Bulletin, 21, 842-849. doi:10.1177/0146167295218007.

Tucker, L. R. (1951). A method for synthesis of factor analysis studies. Washington: Department of the Army.

Twenge, J. M. (2001). Changes in women's assertiveness in response to status and roles: A cross-temporal meta-analysis, 1931-1933. Journal of Personality and Social Psychology, 81, 133-145. doi:10.1037/0022-3514.81.1.133.

United Nations Development Programme (2009) HDR 2009. Overcoming Barriers: Human Mobility and Development. Basingstoke: Palgrave Macmillan.

Van de Vijver, F. J. R., \& Poortinga, Y. H. (1994). Methodological issues in cross-cultural studies on parental rearing behavior and psychopathology. In C. Perris, W. A. Arrindell, \& M. Eisemann (Eds.), Parenting and psychopathology (pp. 173-197). Chichester: Wiley.

Viki, G., \& Abrams, D. (2004). Hostile and benevolent sexism: Complementary system justifying ideologies. Social Psychological Review, 6(2), 76-88.

Walter, N. (2010). Living dolls, the return of sexism. London: Virago Press.

Waylen, G. (2004). What can the South African transition tell us about gender and democratization? Unpublished manuscript, Queens University Belfast.

Williams, J. E., \& Best, D. L. (1982). Measuring sex stereotypes: A thirty-nation study. Beverly Hills: Sage.

Williams, J. E., \& Best, D. L. (1990). Measuring sex stereotypes: A multination study. Beverly Hills: Sage.

Williams, J. E., Satterwhite, R. C., \& Best, D. L. (1999). Pancultural gender stereotypes revisited: The Five Factor Model. Sex Roles, 40, 513-525. doi:10.1023/A:1018831928829.

Yakushko, O. (2005). Ambivalent sexism and relationship patterns among women and men in Ukraine. Sex Roles, 52, 586-596. doi:10.1007/s11199-005-3727-5.

Zahidi, S., \& Ibarra, H. (2010). The corporate gender gap report 2010. Paper presented at the World Economic Forum, Genf. 